\title{
Effect of Lactic Acid Bacteria Isolated from Ensiled Kumpai Tembaga on Growth Performance and Meat Quality of Pegagan Ducks
}

\author{
Fitra Yosi* ${ }^{1}$, Sofia Sandi ${ }^{1}$, Eli Sahara ${ }^{1}$ Meisji Liana Sari ${ }^{1}$ and Nuni Gofar ${ }^{2}$ \\ ${ }^{1}$ Department of Animal Science, Faculty of Agriculture, University of Sriwijaya, South Sumatra, Indonesia \\ ${ }^{2}$ Department of Soil Science, Faculty of Agriculture, University of Sriwijaya, South Sumatra, Indonesia \\ *Corresponding author: fitrayosi@unsri.ac.id
}

\begin{abstract}
\begin{tabular}{llll}
\hline Article History: 21-386 & Received: $30-S e p-21$ & Revised: $13-O c t-21$ & Accepted: $13-O c t-21$ \\
\hline
\end{tabular}
\section{ABSTRACT}

This study aimed to investigate the effect of increasing the lactic acid bacteria (LAB) concentration isolated from ensiled Kumpai Tembaga on the growth performance, carcass yield, and meat quality in Pegagan ducks. A total of 100 Pegagan ducks aged were allocated at seven days into five groups with four replicates: Group 1 (control) and Group 2 to 5 (orally $\mathrm{LAB}$ addition with the concentration of $1 \times 10^{6}, 10^{7}, 10^{8}$, and $10^{9} \mathrm{CFU} / \mathrm{ml}$, respectively). The measured parameters included growth performance, carcass yield, and meat quality. The LAB supplementation significantly affected $(\mathrm{P}<0.05)$ the weekly feed intake, body weight gain, and feed conversion ratio starting from the third week. Irrespective of the LAB concentrations, carcass, and breast cut weights increased $(\mathrm{P}<0.05)$ by 24 and $35.3 \%$, respectively, after LAB supplementation compared to control. The percentage of breast meat and breast meat-to-bone ratio increased $(\mathrm{P}<0.05)$ by 4.0 and $48.05 \%$, respectively, but the bone percentage decreased $(\mathrm{P}<0.05)$ by $9.5 \%$ after LAB addition. Again, irrespective of the $\mathrm{LAB}$ concentrations, the meat shear force declined by $48.05 \%$. $(\mathrm{P}<0.05)$ after administering $\mathrm{LAB}$ compared to the control group. The free fatty acid level dropped by $31.68 \%$ in Groups 3 and 4 and continued decreasing by $44.10 \%(\mathrm{P}<0.05)$ in Group 5. In conclusion, oral LAB supplementation with a concentration of 109 produced optimal growth performance after two weeks of administration. The LAB addition also improved carcass yields, which had a greater impact on the breast. The meat texture became more tender with a lower fatty acid content.
\end{abstract}

Key words: Lactic acid bacteria, Kumpai Tembaga silage, Growth performance, Carcass, Meat quality.

\section{INTRODUCTION}

Lactic acid bacteria (LAB) are one of the most potential bacteria used as feed additives for poultry because of their crucial roles in promoting growth performance or egg production, diminishing the proliferation of the gut pathogenic microbial, improving carcass yield and meat quality, enhancing gut immunity and health, and reducing mortality (Vicente et al. 2007; Gallazzi et al. 2008; Menconi et al. 2011; Salehizadeh et al. 2019; Vieco-Saiz et al. 2019). LAB is a group of gram-positive anaerobic bacteria that mainly produce lactic acid from glucose fermentation (Mokoena 2017). So far, most of the LAB applied for growth promotors are originating from poultry feces, gastrointestinal tract, or fermented products (Surachon et al. 2011; Lee et al. 2016; Salehizadeh et al. 2020), while the utilization of LAB derived from ensiled forage has not been studied. Our previous study has succeeded in isolating and identifying isolates from Kumpai Tembaga silage, which is the local name for the swamp forage of Hymenachne acutigluma. The results confirmed that all the identified isolates are belonged to the LAB group, specifically the Lactobacillus genus (Sandi et al. 2018). According to the in vitro tests, the $\mathrm{LAB}$ isolates had high tolerance in various acidic conditions, either at low (3 to 6.5) or high (7.5 to 8) pH (Sandi et al. 2019).

Determining the concentration of LAB as a feed additive is essential to achieve a significant impact on the poultry. Several studies noted that there were differences in offering the LAB concentration, primarily Lactobacillus, in the diet accompanied with variation in genera and strains, where the broiler responses on the LAB treatments were also varied (Zhu et al. 2009; Peng et al. 2016; Wang et al. 2019). According to those studies, the LAB concentration and genera might be the determining factors to obtain optimal outcomes. Therefore, the evaluation of administering different $\mathrm{LAB}$ concentrations is also needed in this study. The determination of LAB concentrations can be implemented from the LAB content in the gastrointestinal tract, but more information is only available in chickens,

Cite This Article as: Yosi F, Sandi S, Sahara E, Sari ML and Gofar N, 2022. Effect of lactic acid bacteria isolated from ensiled Kumpai Tembaga on growth performance and meat quality of Pegagan ducks. International Journal of Veterinary Science 11(2): 243-248. https://doi.org/10.47278/journal.ijvs/2021.109 
while in ducks is still limited. It was identified that Lactobacillus is a genus of LAB which mostly occupies the gastrointestinal tract of broilers in concentrations of $10^{6}$ to $10^{9} \mathrm{CFU} / \mathrm{g}$ contents (Rehman et al. 2007).

It has been widely proven that $\mathrm{LAB}$ isolated from various sources have positive effects on growth performance, carcass traits, and meat quality in poultry (Forte et al. 2018; Salehizadeh et al. 2019; Wang et al. 2019). However, there has been no study observing the inclusion effect of LAB isolated from ensiled swamp forage on these parameters. Based on our previous investigation, the provision of this LAB was able to increase either the length or weight of the ceca and small intestine segments, as well as reduce serum lipid concentrations in Pegagan duck (Yosi et al. 2020). While its effect on growth performance, carcass characteristics, and meat quality have not been observed. Therefore, further evaluation focusing on the effect of increasing the LAB concentration isolated from ensiled Kumpai Tembaga on the growth performance, carcass yield, and meat quality in Pegagan ducks needs to be performed.

\section{MATERIALS AND METHODS}

\section{Experimental Birds and Management}

All methods and procedures performed in this experiment follow the ethical standards at the Sriwijaya University and the Indonesian government regulation number 18/2009 concerning about health and welfare of farm animals. A total of 100 mixed 1-week-old Pegagan ducks, with initial body weight of $115.31 \pm 5.40 \mathrm{~g}$, was used in this experiment. Pegagan duck is known as the local duck that originated from South Sumatra, Indonesia (Yosi et al. 2016). All birds were assigned to 5 experimental groups with 4 replicates with a total of 20 birds per group. Group 1 was the group without the addition of LAB, then Groups 2 to 5 were the group with LAB supplementation with concentrations of $10^{6}, 10^{7}, 10^{8}$ and $10^{9} \mathrm{CFU} / \mathrm{mL}$, respectively. Birds were kept for 7 weeks, where diets and drinking water were offered ad libitum. Diets, based on the corn-soybean meal, were formulated to meet or exceed nutrient recommendations by the $\mathrm{NRC}$, and divided into starter (0-2 week) and finisher (2-8 week) period diets (Table 1). LAB was administered orally, with the following levels: $3 \mathrm{ml} /$ bird until 3 weeks of age, then gradually increased to $5,7.5$, and $10 \mathrm{~mL}$ at 3 to 5,5 to 7 , and 7 to 8 weeks of age, respectively.

\section{Preparation of Ensiled Kumpai Tembaga}

The detailed steps for making Kumpai Tembaga silage refer to Yosi et al. (2020). The fresh Kumpai Tembaga grass was first cut into smaller pieces of around $2-5 \mathrm{~cm}$ and withered in a room for at least $24 \mathrm{~h}$. After withering, $500 \mathrm{~g}$ of grass was mixed with molasses and water with an amount of $3 \%$ of the weight of the grass. Next, the mixed grass was placed in 3-layer plastic bags and then compacted to anaerobic environments. After 3 weeks of storage, the silage was opened and samples were taken for further laboratory analysis.

\section{LAB Culture and Determination of Concentration}

The procedure for culture and determination of LAB concentration is the same as described by Yosi et al. (2020).
After being cultured on media de man rogosa sharpe (MRS) broth, LAB isolates were incubated at $37^{\circ} \mathrm{C}$ for $48 \mathrm{~h}$. The cultured $\mathrm{LAB}$ was then diluted using $0.85 \% \mathrm{NaCl}$ solution. LAB concentration was determined according to the level of turbidity, by comparing the McFarland standard solution with the diluted LAB solution.

\section{Sample Collection and Analysis}

The growth parameters covering weekly body weight gain (BWG), feed intake (FI), and feed conversion ratio (FCR) were determined. FCR was calculated by dividing the FI with BWG per week. After 7 weeks of rearing, all birds were weighed and 2 birds per replicate were then randomly chosen to determine carcass yield and meat quality parameters. The carcass parameters included carcass weight, carcass slice weight (breast, thigh, wing, and back), as well as the percentage of meat, bones, and meat-to-bone ratio on each carcass cut were recorded. For meat quality, the free fatty acid (FFA) level was measured according to the titration technique as described in the AOAC (2000). Analysis of moisture content (MC) was performed according to the AOAC (2000) method. Shear force (SF) of meat samples was determined using a Warner-Bratzler shear with a load cell of $50 \mathrm{~kg}$ and a crosshead speed of $200 \mathrm{~mm} / \mathrm{min}$ as described by Choo et al. (2014), while the $\mathrm{pH}$, water holding capacity (WHC), and cooking loss (CL) was measured refers to Yosi and Sandi (2014). The determination of SF was based on the average of the highest forces needed to shear respectively set of samples. For $\mathrm{pH}$ determination, $2 \mathrm{~g}$ of each meat sample were mixed with $18 \mathrm{ml}$ of the distilled water, stirred until homogenous, and filtered. $\mathrm{pH}$ meter was first calibrated using 4 and 8 standard solutions and then the $\mathrm{pH}$ of the samples was measured. For WHC measurement, $0.3 \mathrm{~g}$ of breast meat was located on Whatman 41 filter paper and then positioned between 2 metal plates with a pressure capacity of $35 \mathrm{~kg}$ for $5 \mathrm{~min}$ to create the wet area on the filter paper. To determine the wet area, it was computed by subtracting the total area with the area-covered meat samples. For measuring CL, a total of $20 \mathrm{~g}$ of breast meat was put in polyethylene plastic, sealed using a vacuum pack, and heated in a water bath for $30 \mathrm{~min}$ at $80^{\circ} \mathrm{C}$ until cooked. The samples were cooled at room temperature, dried with filter paper on their surface, and then reweighed with analytical balance The CL was determined from the difference in sample weight between before and after cooking.

\section{Statistical Analysis}

All collected data in this study were analysed using SPSS statistical software (SPSS version 17). The obtained data were subjected to one-way analysis of variance for completely randomized design. Differences among main effect means $(\mathrm{P} \leq 0.05)$ were assessed via Duncan's multiple range tests. Statistical significance was verified based on $\mathrm{P} \leq 0.05$.

\section{RESULTS}

\section{Effects on Growth Performance}

The LAB supplementation of ensiled Kumpai Tembaga had a significant effect $(\mathrm{P}<0.05)$ on FI, BWG, and FCR of Pegagan ducks from the third week to the last week of rearing (Table 2). At week 3, the FI appeared to be lower $(\mathrm{P}<0.05)$, whereas BWG increased up to $23,3 \%$ after 
Int J Vet Sci, 2022, 11(2): 243-248

Table 1: Nutrient composition and ingredients on the experimental diet ( $\mathrm{g} / \mathrm{kg}$ diet as fed basis)

\begin{tabular}{lcc}
\hline Ingredients & \multicolumn{2}{c}{ Composition (\%) } \\
\cline { 2 - 3 } & Starter phase $(0-2$ week) & finisher phase $(2-8$ week) \\
\hline Soybean meal & 28 & 68 \\
Corn meal & 56 & 5 \\
Meat bone meal (MBM) & 6 & 10 \\
Bran & 9 & 0.5 \\
Grit & 0.5 & 0.5 \\
Vitamin-mineral premix ${ }^{\mathrm{a}}$ & 0.5 & 3109 \\
Calculated chemichal composition $^{\mathrm{b}}$ & & 7.96 \\
ME (Kcal/kg) & 2910 & 18.16 \\
Crude fiber $(\%)$ & 6.24 & 0.85 \\
Crude protein $(\%)$ & 22.06 & 0.52 \\
Ca (\%) & 0.99 & 0.52
\end{tabular}

aprovided per kilogram of diet: lysine $\mathrm{HCL}=5,000 \mathrm{mg}$; methionine $=3,400 \mathrm{mg}$; vitamin $\mathrm{A}=5,000,0000 \mathrm{IU}$; vitamin $\mathrm{B} 12=3,800 \mathrm{mg}$; vitamin $\mathrm{E}=450 \mathrm{IU}$; vitamin $\mathrm{D} 3=1,500,000 \mathrm{IU}$; vitamin $\mathrm{B} 2=1,500 \mathrm{mg}$; vitamin $\mathrm{B} 6=780 \mathrm{mg}$; vitamin $\mathrm{K}=1,500 \mathrm{mg}$; vitamin $\mathrm{C}=330 \mathrm{mg}$; niacin $=5,580 \mathrm{mg} ;$ zinc sulphate $=4,000 \mathrm{mg} ;$ pantotenate acid $=1,800 \mathrm{mg} ;$ magnesium $=4,000 \mathrm{mg} ;$ cooper $=4,000 \mathrm{mg}$; sodium sulphate $=70,0000 \mathrm{mg}$; sodium chloride $=16,500 \mathrm{mg}$; manganese $=4,000 \mathrm{mg}$; potasium chloride $=29,000 \mathrm{mg}$ : ${ }^{\text {b }}$ Calculated referring to National Research Council (1994).

Table 2: Weekly feed intake, body weight gain, and feed conversion ratio of Pegagan ducks supplemented with different concentrations of LAB isolated from ensiled Kumpai Tembaga

\begin{tabular}{|c|c|c|c|c|c|}
\hline \multirow[t]{2}{*}{ Item } & \multicolumn{5}{|c|}{ Concentration of LAB solutions (CFU/ml) } \\
\hline & Group 1 (Control) & Group $2\left(10^{6}\right)$ & Group $3\left(10^{7}\right)$ & Group $4\left(10^{8}\right)$ & Group $5\left(10^{9}\right)$ \\
\hline \multicolumn{6}{|l|}{ Week 1} \\
\hline FI (kg/bird) & $0.28 \pm 0.05$ & $0.29 \pm 0.05$ & $0.25 \pm 0.02$ & $0.27 \pm 0.02$ & $0.29 \pm 0.06$ \\
\hline BWG (kg/bird) & $0.100 \pm 0.013$ & $0.099 \pm 0.014$ & $0.100 \pm 0.014$ & $0.107 \pm 0.004$ & $0.102 \pm 0.034$ \\
\hline FCR & $2.90 \pm 0.70$ & $2.93 \pm 0.45$ & $2.55 \pm 0.28$ & $2.49 \pm 0.21$ & $2.78 \pm 0.26$ \\
\hline \multicolumn{6}{|l|}{ Week 2} \\
\hline FI (kg/bird) & $0.41 \pm 0.09$ & $0.42 \pm 0.09$ & $0.35 \pm 0.02$ & $0.36 \pm 0.07$ & $0.32 \pm 0.06$ \\
\hline BWG (kg/bird) & $0.109 \pm 0.011$ & $0.118 \pm 0.029$ & $0.109 \pm 0.010$ & $0.117 \pm 0.015$ & $0.116 \pm 0.013$ \\
\hline FCR & $3.75 \pm 0.88$ & $3.82 \pm 1.50$ & $3.22 \pm 0.24$ & $3.11 \pm 0.52$ & $2.83 \pm 0.67$ \\
\hline \multicolumn{6}{|l|}{ Week 3} \\
\hline FI (kg/bird) & $0.62 \pm 0.01^{\mathrm{ab}}$ & $0.66 \pm 0.05^{\mathrm{a}}$ & $0.59 \pm 0.06^{\mathrm{abc}}$ & $0.52 \pm 0.01^{\mathrm{c}}$ & $0.54 \pm 0.11^{\mathrm{bc}}$ \\
\hline BWG (kg/bird) & $0.130 \pm 0.008^{b}$ & $0.161 \pm 0.006^{\mathrm{a}}$ & $0.159 \pm 0.013^{\mathrm{a}}$ & $0.157 \pm 0.004^{\mathrm{a}}$ & $0.164 \pm 0.053^{\mathrm{a}}$ \\
\hline FCR & $4.80 \pm 0.22^{\mathrm{a}}$ & $4.10 \pm 0.25^{\mathrm{b}}$ & $3.69 \pm 0.31^{b c}$ & $3.32 \pm 0.28^{c}$ & $3.27 \pm 0.45^{\mathrm{c}}$ \\
\hline \multicolumn{6}{|l|}{ Week 4} \\
\hline FI (kg/bird) & $0.75 \pm 0.03^{b}$ & $0.78 \pm 0.05^{\mathrm{b}}$ & $0.76 \pm 0.02^{\mathrm{b}}$ & $0.77 \pm 0.03^{b}$ & $0.84 \pm 0.04^{\mathrm{a}}$ \\
\hline BWG (kg/bird) & $0.176 \pm 0.006^{\mathrm{b}}$ & $0.212 \pm 0.032^{\mathrm{b}}$ & $0.211 \pm 0.015^{\mathrm{b}}$ & $0.206 \pm 0.013^{\mathrm{b}}$ & $0.258 \pm 0.019^{\mathrm{a}}$ \\
\hline FCR & $4.29 \pm 0.19^{\mathrm{a}}$ & $3.71 \pm 0.37^{\mathrm{b}}$ & $3.62 \pm 0.15^{\mathrm{b}}$ & $3.74 \pm 0.08^{b}$ & $3.34 \pm 0.59^{b}$ \\
\hline \multicolumn{6}{|l|}{ Week 5} \\
\hline FI (kg/bird) & $1.20 \pm 0.01^{\mathrm{b}}$ & $1.21 \pm 0.02^{\mathrm{b}}$ & $1.18 \pm 0.04^{\mathrm{b}}$ & $1.17 \pm 0.04^{\mathrm{b}}$ & $1.35 \pm 0.14^{\mathrm{a}}$ \\
\hline BWG (kg/bird) & $0.187 \pm 0.010^{b}$ & $0.192 \pm 0.007^{b}$ & $0.190 \pm 0.030^{\mathrm{b}}$ & $0.192 \pm 0.013^{\mathrm{b}}$ & $0.234 \pm 0.013^{\mathrm{a}}$ \\
\hline FCR & $6.44 \pm 0.44^{\mathrm{a}}$ & $6.34 \pm 0.34^{\mathrm{a}}$ & $6.27 \pm 0.20^{\mathrm{a}}$ & $6.13 \pm 0.04^{\mathrm{ab}}$ & $5.77 \pm 0.21^{\mathrm{b}}$ \\
\hline \multicolumn{6}{|l|}{ Week 6} \\
\hline FI (kg/bird) & $1.04 \pm 0.04^{\mathrm{b}}$ & $1.12 \pm 0.05^{\mathrm{ab}}$ & $1.10 \pm 0.02^{\mathrm{b}}$ & $1.12 \pm 0.06^{\mathrm{ab}}$ & $1.20 \pm 0.09^{\mathrm{a}}$ \\
\hline BWG (kg/bird) & $0.158 \pm 0.006^{\mathrm{b}}$ & $0.169 \pm 0.003^{b}$ & $0.168 \pm 0.013^{\mathrm{b}}$ & $0.169 \pm 0.025^{\mathrm{b}}$ & $0.189 \pm 0.020^{\mathrm{a}}$ \\
\hline FCR & $6.62 \pm 0.14^{\mathrm{a}}$ & $6.64 \pm 0.08^{\mathrm{a}}$ & $6.54 \pm 0.10^{\mathrm{ab}}$ & $6.65 \pm 0.15^{\mathrm{a}}$ & $6.37 \pm 0.17^{b}$ \\
\hline \multicolumn{6}{|l|}{ Week 7} \\
\hline FI (kg/bird) & $1.14 \pm 0.06^{\mathrm{b}}$ & $1.16 \pm 0.13^{\mathrm{b}}$ & $1.19 \pm 0.07^{\mathrm{b}}$ & $1.15 \pm 0.10^{\mathrm{b}}$ & $1.55 \pm 0.40^{\mathrm{a}}$ \\
\hline BWG (kg/bird) & $0.153 \pm 0.013^{b}$ & $0.157 \pm 0.017^{b}$ & $0.163 \pm 0.011^{\mathrm{b}}$ & $0.164 \pm 0.073^{b}$ & $0.221 \pm 0.048^{a}$ \\
\hline FCR & $7.45 \pm 0.32^{\mathrm{a}}$ & $7.46 \pm 0.11^{\mathrm{a}}$ & $7.33 \pm 0.21^{\mathrm{ab}}$ & $7.06 \pm 0.06^{\mathrm{b}}$ & $7.07 \pm 0.07^{b}$ \\
\hline
\end{tabular}

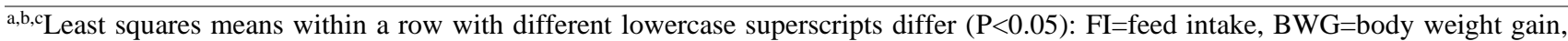
$\mathrm{FCR}=$ feed conversion ratio.

the LAB supplementation. Afterward, from week 4 to 7 , the FI after supplementing LAB with the concentration of $10^{9}$ increased $(\mathrm{P}<0.05)$ by 9.6 to $33.6 \%$, while BWG improved $(\mathrm{P}<0.05)$ by 13.9 to $38.8 \%$ compared to both control and other LAB concentrations. For the FCR, it declined by $18.9 \%$ and $31.4 \%$ in the third week after adding LAB up to $10^{7}$ and $10^{9} \mathrm{CFU} / \mathrm{ml}$, respectively. At week 4, there was a decrease in FCR by $10.5 \%(\mathrm{P}<0.05)$ after the addition of LAB compared to the control, but the differences in LAB concentrations presented the similar response to this parameter. From week 5 to 6 , FCR reduced $(\mathrm{P}<0.05)$ by 8.3 and $3.7 \%$ respectively after introducing LAB supplementation of $10^{9} \mathrm{CFU} / \mathrm{mL}$, while FCR between control and $\mathrm{LAB}$ treatments up to a concentration of $10^{8}$ was not different. In the seventh week, a decrease in FCR occurred by $4.7 \%(\mathrm{P}<0.05)$ after the addition of LAB starting from the concentration of $10^{8} \mathrm{CFU} / \mathrm{mL}$.

\section{Effects on Carcass Yields}

The LAB supplementation, irrespective of the LAB concentrations, affected $(\mathrm{P}<0.05)$ the whole carcass and breast weights, while the wings, thighs, and back weights did not change after the addition of LAB (Table 3 ). The weights of whole carcass and breast increased $(\mathrm{P}<0.05)$ 
Int J Vet Sci, 2022, 11(2): 243-248

Table 3: Carcass yield and meat to bone ratio in each carcass slice of Pegagan ducks after supplementing with LAB solutions isolated from ensiled Kumpai Tembaga

\begin{tabular}{lccccc}
\hline Item & \multicolumn{5}{c}{ Concentration of LAB solutions (CFU/ml) } \\
\cline { 2 - 6 } & Group 1 (Control) & Group 2 $\left(10^{6}\right)$ & Group 3 $\left(10^{7}\right)$ & Group 4 $\left(10^{8}\right)$ & Group 5 $\left(10^{9}\right)$ \\
\hline Carcass (kg) & $0.570 \pm 0.003^{\mathrm{b}}$ & $0.671 \pm 0.028^{\mathrm{a}}$ & $0.683 \pm 0.027^{\mathrm{a}}$ & $0.715 \pm 0.017^{\mathrm{a}}$ & $0.749 \pm 0.035^{\mathrm{a}}$ \\
Breast (kg) & $0.162 \pm 0.002^{\mathrm{b}}$ & $0.207 \pm 0.009^{\mathrm{a}}$ & $0.213 \pm 0.009^{\mathrm{a}}$ & $0.223 \pm 0.003^{\mathrm{a}}$ & $0.234 \pm 0.012^{\mathrm{a}}$ \\
Meat (\%) & $70.54 \pm 0.13^{\mathrm{b}}$ & $72.14 \pm 1.98^{\mathrm{ab}}$ & $73.61 \pm 2.26^{\mathrm{a}}$ & $73.86 \pm 0.88^{\mathrm{a}}$ & $73.75 \pm 2.36^{\mathrm{a}}$ \\
Bone (\%) & $29.46 \pm 0.12^{\mathrm{a}}$ & $27.86 \pm 1.98^{\mathrm{ab}}$ & $26.40 \pm 2.26^{\mathrm{b}}$ & $26.13 \pm 0.89^{\mathrm{b}}$ & $26.24 \pm 2.37^{\mathrm{b}}$ \\
Meat:bone ratio & $2.39 \pm 0.02^{\mathrm{b}}$ & $2.61 \pm 0.27^{\mathrm{ab}}$ & $2.81 \pm 0.36^{\mathrm{a}}$ & $2.83 \pm 0.13^{\mathrm{a}}$ & $2.84 \pm 0.34^{\mathrm{a}}$ \\
Thighs (kg) & $0.152 \pm 0.003$ & $0.178 \pm 0.010$ & $0.175 \pm 0.005$ & $0.184 \pm 0.011$ & $0.192 \pm 0.014$ \\
Meat (\%) & $77.64 \pm 1.67$ & $78.31 \pm 2.56$ & $78.42 \pm 2.53$ & $77.95 \pm 3.73$ & $77.98 \pm 4.48$ \\
Bone (\%) & $22.36 \pm 1.67$ & $21.68 \pm 2.55$ & $21.58 \pm 2.53$ & $22.05 \pm 3.73$ & $22.02 \pm 4.47$ \\
Meat:bone ratio & $3.49 \pm 0.36$ & $3.66 \pm 0.57$ & $3.68 \pm 0.54$ & $3.63 \pm 0.77$ & $3.69 \pm 0.96$ \\
Wings (kg) & $0.096 \pm 0.003$ & $0.109 \pm 0.003$ & $0.112 \pm 0.006$ & $0.117 \pm 0.003$ & $0.124 \pm 0.009$ \\
Meat (\%) & $46.53 \pm 1.85$ & $45.92 \pm 4.74$ & $46.89 \pm 9.07$ & $47.54 \pm 3.73$ & $47.25 \pm 7.34$ \\
Bone (\%) & $53.47 \pm 1.84$ & $54.08 \pm 4.74$ & $53.11 \pm 9.07$ & $52.47 \pm 3.73$ & $52.75 \pm 7.33$ \\
Meat:bone ratio & $0.87 \pm 0.07$ & $0.86 \pm 0.15$ & $0.92 \pm 0.31$ & $0.91 \pm 0.13$ & $0.92 \pm 0.26$ \\
Back (kg) & $0.158 \pm 0.003$ & $0.176 \pm 0.009$ & $0.183 \pm 0.010$ & $0.190 \pm 0.005$ & $0.198 \pm 0.005$ \\
Meat (\%) & $23.84 \pm 3.04$ & $23.28 \pm 5.58$ & $24.80 \pm 2.96$ & $24.39 \pm 2.88$ & $22.99 \pm 3.79$ \\
Bone (\%) & $76.16 \pm 3.04$ & $76.72 \pm 5.57$ & $75.20 \pm 2.95$ & $75.61 \pm 2.88$ & $77.00 \pm 3.79$ \\
Meat:bone ratio & $0.32 \pm 0.11$ & $0.33 \pm 0.19$ & $0.33 \pm 0.10$ & $0.33 \pm 0.10$ & $0.31 \pm 0.14$ \\
\hline
\end{tabular}

a,b Least squares means within a row with different lowercase superscripts differ $(\mathrm{P}<0.05)$.

Table 4: Meat quality of Pegagan ducks after supplementing with LAB solutions isolated from ensiled Kumpai Tembaga

\begin{tabular}{lccccc}
\hline Item & \multicolumn{5}{c}{ Concentration of LAB solutions (CFU/ml) } \\
\cline { 2 - 6 } & Group 1 (Control) & Group 2 $\left(10^{6}\right)$ & Group 3 $\left(10^{7}\right)$ & Group 4 $\left(10^{8}\right)$ & Group 5 $\left(10^{9}\right)$ \\
\hline pH & $6.29 \pm 0.38$ & $6.34 \pm 0.33$ & $6.04 \pm 0.07$ & $6.35 \pm 0.47$ & $6.01 \pm 0.11$ \\
SF (N) & $59.75 \pm 4.93^{\mathrm{a}}$ & $31.30 \pm 2.83^{\mathrm{b}}$ & $31.00 \pm 4.82^{\mathrm{b}}$ & $30.60 \pm 4.74^{\mathrm{b}}$ & $31.25 \pm 5.70^{\mathrm{b}}$ \\
WHC (\%) & $55.16 \pm 1.45$ & $54.55 \pm 1.44$ & $57.61 \pm 1.93$ & $59.35 \pm 1.42$ & $58.67 \pm 2.60$ \\
CL (\%) & $41.12 \pm 1.21$ & $41.14 \pm 1.72$ & $42.88 \pm 1.38$ & $42.56 \pm 1.24$ & $42.89 \pm 1.17$ \\
MC (\%) & $77.58 \pm 0.70$ & $77.13 \pm 1.29$ & $77.49 \pm 2.03$ & $78.01 \pm 0.92$ & $77.20 \pm 0.51$ \\
FFA (\%) & $0.81 \pm 0.02^{\mathrm{a}}$ & $0.80 \pm 0.02^{\mathrm{a}}$ & $0.56 \pm 0.01^{\mathrm{b}}$ & $0.54 \pm 0.02^{\mathrm{b}}$ & $0.45 \pm 0.05^{\mathrm{c}}$ \\
\hline
\end{tabular}

$\overline{\mathrm{a}, \mathrm{b}, \mathrm{c}}$ Least squares means within a row with different lowercase superscripts differ $(\mathrm{P}<0.05)$ : $\mathrm{SF}=$ shear force, WHC $=$ water holding capacity, $\mathrm{CL}=$ cooking loss, $\mathrm{MC}=$ moisture content, $\mathrm{FFA}=$ free fatty acids.

by 24 and $35.3 \%$, respectively, after LAB supplementation compared to control. Furthermore, there was a significant effect $(\mathrm{P}<0.05)$ on the percentage of meat, bones, and the ratio of meat and bones in breast slices, while the same response was shown on the wings, thighs, and back slices after adding LAB compared to control. The percentage of breast meat increased $(\mathrm{P}<0.05)$ by $4.0 \%$, but the bone percentage decreased $(\mathrm{P}<0.05)$ by $9.5 \%$ after $\mathrm{LAB}$ addition. The meat-to-bone ratio, irrespective of the LAB concentrations, also increased by $16.0 \%$ with LAB supplementation compared to control.

\section{Effects on Meat Quality}

The provision of LAB solutions significantly $(\mathrm{P}<0.05)$ affected the SF and FFA content in duck meat, while no significant influence was detected on $\mathrm{pH}$, WHC, CL, and MC (Table 4). Irrespective of the LAB concentrations, the meat shear force with LAB supplementation was lower $(\mathrm{P}<0.05)$ than control, with a decrease of $48.05 \%$. Furthermore, there was a $31.68 \%$ decrease in FFA content after LAB supplementation with a concentration of $10^{7}$ and $10^{8} \mathrm{CFU} / \mathrm{ml}$, and it continued decreasing by $44.10 \%$ $(\mathrm{P}<0.05)$ when LAB was added with a concentration of $10^{9}$ $\mathrm{CFU} / \mathrm{ml}$ compared to the control and a $\mathrm{LAB}$ concentration of $10^{6} \mathrm{CFU} / \mathrm{ml}$.

\section{DISCUSSION}

The LAB administration during the first 2 weeks did not significantly affect the growth performance. This is also supported by another study that the effect of administering
LAB strains on broilers performance during the finisher and growth period was greater than that of during the starter period (Kalavathy et al. 2003; Peng et al. 2016). It is assumed that the LAB, especially Lactobacillus genera, have not developed properly in the duck's alimentary tract during the early weeks of life. Some studies reported that the development of Lactobacillus in the small intestine of chickens, including duodenum, jejunum, and ileum, started to increase and became dominant after 2 weeks of age (Rehman et al. 2007). The provision of LAB with concentrations ranging from $10^{8}$ to $10^{9} \mathrm{CFU} / \mathrm{ml}$ seemed to be the optimal dosage to promote growth performance after the third week, both for increasing BWG and improving FCR. This is in line with a study conducted by Forte et al. (2018) that the use of Lactobacillus with a concentration of $1 \times 10^{9} \mathrm{CFU} / \mathrm{kg}$ of feed is highly recommended to improve the growth performance of chickens. The lower feed conversion also occurred in broiler chickens supplemented with two LAB strains with concentration of 6-7 $\times 10^{10}$ $\mathrm{CFU} / \mathrm{kg}$ diet, indicating that the efficiency of using feed was higher than treatment without LAB (Fajardo et al. 2012). The increase in BWG in this study indicated that the absorption of nutrients in the gastrointestinal tract after LAB supplementation is greater, therefore the process of forming tissue protein for body growth is becoming optimal. The ability to absorb feed nutrients is largely determined by the histomorphological indicators of the small intestine, especially the size of the villus, where the increase the villus height will enlarge the surface area of the small intestine, so that the ability to absorb the available nutrients in the intestinal lumen is greater (Chichlowski et 
al. 2007). Some investigations demonstrated that the height of jejunal and ileal villi in chicken was increasing after supplementation with Lactobacillus group (Forte et al. 2018; Wang et al. 2019). Our previous observation also revealed that there was an increase in the weight and length of the small intestine after LAB supplementation (Yosi et al. 2020). This might be related to the increase in the surface area of the small intestine due to the higher villus height.

The higher carcass weight and breast yield observed in the LAB supplemented groups is attributed to higher BWG in the ducks of these groups. These carcass improvements could be due to their ability to enhance the bioavailability of nutrients and increase digestive enzymes thereby promoting the growth of muscle tissues (Aguihe et al. 2017). Improvements in carcass and breast yield were also noted in broiler chicken after supplementing probiotic LAB (Salehizadeh et al. 2019). However, a study performed by Wang and Zhou (2007) showed that no effect was found on the whole carcass and breast weight of 7-week-old meat ducks after supplementation with LAB strains in the diet. The variations of bacterial strain used in some studies could be a determining factor that causes differences in the results obtained (Otutumi et al. 2012; Cruz et al. 2019). Not only increasing the proportion of meat, but bone weight also increased after LAB supplementation. This might be attributed to higher calcium absorption in the gut lumen and assimilation in the bone, which created a greater proportion of bone. However, there is no well-established link between $\mathrm{LAB}$ and bone mineralization so far. Therefore, further investigations are needed to identify the specific mechanism of LAB on bone development in ducks and the LAB action mode on bone mineralization. A study investigated by Panda et al. (2006) reported that dietary supplementation of Lactobacillus strain resulted in higher serum concentration of $\mathrm{Ca}$ and improved bone breaking strength and bone ash content. Another experiment by Ziarat et al. (2020) using dietary LAB supplementation also confirmed that the use of Lactobacillus strains increased the length of the tibia bone and improved bone calcium and phosphorus contents. Nevertheless, the ratio of meat to the bone in the supplemented group was higher than that in the control group, indicating that meat formation still dominates over bone, and this is certainly to be expected in meat duck production.

Shear force is one indicator that can be used to determine the tenderness of the meat, where the lower value of shear force, the higher the tenderness of meat (Barbanti and Pasquini 2005). The decreasing of shear force in this study indicated an improvement in intramuscular quality after LAB supplementation. Another study also showed a decrease in the shear-force of 42-dayold broiler meat after administration of Lactobacillus strain in the diet, with a lower value than the results of this study, which was 29.6-42.9N (Wang et al. 2019). Moreover, FFA is one of the most common chemical parameters used to determine the quality of a product (Ozkececi et al. 2008). The increase in the FFA value in meat muscles is primary caused by lipolysis, which is then suspected to promote the spoilage in foodstuff (Soyer et al. 2010; Yousefi et al. 2018). The decrease in FFA after LAB supplementation indicated the administration of LAB could inhibit the lipolysis of meat. The lower fat content in breast meat after
LAB supplementation in this study probably was the main reason for the low FFAs production in meat samples compared to the control treatment.

\section{Conclusion}

It was concluded that the oral LAB supplementation with a concentration of $1 \times 10^{9} \mathrm{CFU} / \mathrm{ml}$ produces optimal growth performance after 2 weeks of LAB administration. The administration of $\mathrm{LAB}$ is able to improve carcass yields, which has a greater impact on the breast slices. The meat texture becomes more tender with a lower free fatty acid content.

\section{Acknowledgment}

The author would like to thank the Research Institute of Sriwijaya University which has provided research funds through the "Professional Grant" with the contract: 1023/UN9.3.1/LPMP/2016

\section{Author's Contribution}

FY, NG, and SS conceptualized and designed the experiment. FY and MLS conducted an in vivo experiment and collected all samples. FY, ES and SS analyzed the data statistically. FY prepared the first manuscript. All authors corrected and approved the final revision of manuscript.

\section{REFERENCES}

Aguihe PC, Kehinde AS, Abdulmumini S, Ospina-Rojas IC and Murakami AE, 2017. Effect of dietary probiotic supplementation on carcass traits and haematological responses of broiler chickens fed shea butter cake based diets. Acta Scientiarum - Animal Sciences 39: 265-271. https://doi.org/10.4025/actascianimsci.v39i3.34813

AOAC, 2000. Official Methods of Analysis of AOAC International. $17^{\text {th }}$ Ed. Gaithersburg, MD, USA

Barbanti D and Pasquini M, 2005. Influence of cooking conditions on cooking loss and tenderness of raw and marinated chicken breast meat. LWT - Food Science and Technology 38: 895-901. https://doi.org/10.1016/j.lwt. 2004.08.017

Chichlowski M, Croom WJ, Edens FW, McBride BW, Qiu R, Chiang CC, Daniel LR, Havenstein GB and Koci MD, 2007. Microarchitecture and spatial relationship between bacteria and ileal, cecal, and colonic epithelium in chicks fed a directfed microbial, PrimaLac and salinomycin. Poultry Science 86: 1121-1132. https://doi.org/10.1093/ps/86.6.1121

Choo YK, Kwon HJ, Oh ST, Um JS, Kim BG, Kang CW, Lee SK and An BK, 2014. Comparison of growth performance, carcass characteristics and meat quality of Korean local chickens and silky fowl. Asian-Australasian Journal of Animal Sciences 27: 398-405. https://doi.org/10.5713/ajas. $\underline{2013.13638}$

Cruz PJD, Dagaas CT, Mangubat KMM, Angeles AA and Abanto OD, 2019. Dietary effects of commercial probiotics on growth performance, digestibility, and intestinal morphometry of broiler chickens. Tropical Animal Health and Production 51: 1105-1115. https://doi.org/10.1007/s11 250-018-01791-0

Fajardo P, Pastrana L, Méndez J, Rodríguez I, Fucios C and Guerra NP, 2012. Effects of feeding of two potentially probiotic preparations from lactic acid bacteria on the performance and faecal microflora of broiler chickens. The Scientific World Journal 2012: 14-16. https://doi.org/ $\underline{10.1100 / 2012 / 562635}$

Forte C, Manuali E, Abbate Y, Papa P, Vieceli L, Tentellini M, Trabalza-Marinucci $M$ and Moscati L, 2018. Dietary 
Lactobacillus acidophilus positively influences growth performance, gut morphology, and gut microbiology in rurally reared chickens. Poultry Science 97: 930-936. https://doi.org/10.3382/ps/pex396

Gallazzi D, Giardini A, Mangiagalli MG, Marelli S, Ferrazzi V, Orsi C and Cavalchini LG, 2008. Effects of Lactobacillus acidophilus D2/CSL on laying hen performance. Italian Journal of Animal Science 7: 27-37. https://doi.org/10.4081/ ijas. 2008.27

Kalavathy R, Abdullah N, Jalaludin S and Ho YW, 2003. Effects of Lactobacillus cultures on growth performance, abdominal fat deposition, serum lipids and weight of organs of broiler chickens. British Poultry Science 44: 139-144. https://doi.org/10.1080/0007166031000085445

Lee KW, Shim JM, Park SK, Heo HJ, Kim HJ, Ham KS and Kim $\mathrm{JH}, 2016$. Isolation of lactic acid bacteria with probiotic potentials from kimchi, traditional Korean fermented vegetable. LWT-Food Science and Technology 71: 130137. https://doi.org/10.1016/j.lwt.2016.03.029

Menconi A, Wolfenden AD, Shivaramaiah S, Terraes JC, Urbano T, Kuttel J, Kremer C, Hargis BM and Tellez G, 2011. Effect of lactic acid bacteria probiotic culture for the treatment of Salmonella enterica serovar Heidelberg in neonatal broiler chickens and Turkey poults. Poultry Science 90: 561-565. https://doi.org/10.3382/ps.2010-01220

Mokoena MP, 2017. Lactic acid bacteria and their bacteriocins: Classification, biosynthesis and applications against uropathogens: A mini-review. Molecules 22: 1255. https://doi.org/10.3390/molecules22081255

Otutumi LK, Gois BM, Gracia ERM and Loddi MM, 2012. Variations on the efficacy of probiotics in poultry probiotic in animals. Rigobelo EC (Ed), IntechOpen. https://doi.org/https://doi.org/10.5772/50058

Ozkececi RB, Karakaya M, Yilmaz MT, Saricoban C and Ockerman HW, 2008. The effect of carcass part and packaging method on the storage stability of mechanically deboned chicken meat. Journal of Muscle Foods 19: 288 301. https://doi.org/10.1111/j.1745-4573.2008.00118.x

Panda AK, Rao SVR, Raju MVLN and Sharma SR, 2006. Dietary supplementation of Lactobacillus sporogenes on performance and serum biochemico-lipid profile of broiler chickens. The Journal of Poultry Science 43: 235-240. https://doi.org/10.2141/jpsa.43.235

Peng Q, Zeng XF, Zhu JL, Wang S, Liu XT, Hou CL, Thacker PA and Qiao SY, 2016. Effects of dietary Lactobacillus plantarum B1 on growth performance, intestinal microbiota, and short chain fatty acid profiles in broiler chickens. Poultry Science 95: 893-900. https://doi.org/10.3382/ps/pev435

Rehman HU, Vahjen W, Awad WA and Zentek J, 2007. Indigenous bacteria and bacterial metabolic products in the gastrointestinal tract of broiler chickens. Archives of Animal Nutrition 61: 319-335. https://doi.org/10.1080/17450390 701556817

Salehizadeh M, Modarressi MH, Mousavi SN and Ebrahimi MT, 2019. Effects of probiotic lactic acid bacteria on growth performance, carcass characteristics, hematological indices, humoral immunity, and IGF-I gene expression in broiler chicken. Tropical Animal Health and Production 51: 22792286. https://doi.org/10.1007/s11250-019-01935-w

Salehizadeh M, Modarressi MH, Mousavi SN and Ebrahimi MT, 2020. Evaluation of lactic acid bacteria isolated from poultry feces as potential probiotic and its in vitro competitive activity against Salmonella typhimurium. Veterinary Research Forum 11: 67-75. https://doi.org/10.30466/vrf. 2018.84395.2110

Sandi S, Miksusanti M, Sari ML, Sahara E, Supriyadi A, Gofar N and Asmak A, 2019. Acid resistance test of probiotic isolated from silage forage swamp on in vitro digestive tract. Indonesian Journal of Fundamental and Applied Chemistry 4: 15-19. https://doi.org/10.24845/ijfac.v4.i1.15
Sandi S, Yosi F, Sari ML and Gofar N, 2018. The characteristics and potential of lactic acid bacteria as probiotics in silage made from Hymenachne acutigluma and Neptunia oleracea lour. E3S Web of Conferences 68: 1-4. https://doi.org/ $\underline{10.1051 / \mathrm{e} 3 \text { sconf/20186801017 }}$

Soyer A, Özalp B, Dalmiş Ü and Bilgin V, 2010. Effects of freezing temperature and duration of frozen storage on lipid and protein oxidation in chicken meat. Food Chemistry 120: 1025-1030. https://doi.org/10.1016/j.foodchem.2009.11.042

Surachon P, Sukon P, Chaveerach P, Waewdee P and Soikum C, 2011. Screening of lactic acid bacteria isolated from chicken ceca for in vitro growth inhibition of Salmonella enteritica serovar Enteritidis. Journal of Animal and Veterinary Advances 10: 939-944. https://doi.org/10.3923/javaa. 2011. 939.944

Vicente JL, Aviña L, Torres-Rodriguez A, Hargis B and Tellez G, 2007. Effect of a Lactobacillus spp-based probiotic culture product on broiler chicks performance under commercial conditions. International Journal of Poultry Science 6: 154156. https://doi.org/10.3923/ijps.2007.154.156

Vieco-Saiz N, Belguesmia Y, Raspoet R, Auclair E, Gancel F, Kempf I and Drider D, 2019. Benefits and inputs from lactic acid bacteria and their bacteriocins as alternatives to antibiotic growth promoters during food-animal production. Frontiers in Microbiology 10: 1-17. https://doi.org/ 10.3389/ fmicb.2019.00057

Wang J and Zhou H, 2007. Comparison of the effects of Chinese herbs, probiotics and prebiotics with those of antibiotics in diets on the performance of meat ducks. Journal of Animal and Feed Sciences 16: 96-103. https://doi.org/ 10.22358/ jafs/66730/2007

Wang L, Feng Y, Zhang X and Wu G, 2019. Effect of probiotic Lactobacillus reuteri $\mathrm{XC} 1$ coexpressing endoglucanase and phytase on intestinal $\mathrm{pH}$ and morphology, carcass characteristics, meat quality and serum biochemical indexes of broiler chickens. Revista Brasileira de Zootecnia 48: 111. https://doi.org/10.1590/RBZ4820180273

Yosi F and Sandi S, 2014. Meat quality, blood profile, and fecal ammonia concentration of broiler supplemented with liquid smoke. Media Peternakan 37: 169-174. https://doi.org/ 10.5398/medpet.2014.37.3.169

Yosi F, Sandi S, Miksusanti, Rofiq N and Sutejo, 2016. Nutrient digestibility in pegagan ducks fed diet containing locally sourced ingredients fermented with yeast inoculum. International Journal of Poultry Science 15: 103-110 https://doi.org/10.3923/ijps.2016.103.110

Yosi F, Sandi S, Gofar N, Sari ML and Sahara E, 2020. Supplementation of lactic acid bacteria derived from ensiled kumpai tembaga on live body weight, gastrointestinal tract, internal organs, and blood profiles in pegagan ducks. Advances in Animal and Veterinary Sciences 8: 916-924. https://doi.org/10.17582/journal.aavs/2020/8.9.916.924

Yousefi M, Farshidi M and Ehsani A, 2018. Effects of lactoperoxidase system-alginate coating on chemical, microbial, and sensory properties of chicken breast fillets during cold storage. Journal of Food Safety 38: 1-9. https://doi.org/10.1111/jfs. 12449

Zhu NH, Zhang RJ, Wu H and Zhang B, 2009. Effects of Lactobacillus cultures on growth performance, xanthophyll deposition, and color of the meat and skin of broilers. Journal of Applied Poultry Research 18: 570-578. https://doi.org/ 10.3382/japr.2009-00012

Ziarat MM, Kermanshahi H, Mogaddam HN and Heravi RM, 2020. Performance of an Escherichia coli phytase expressed in Lactococcus lactis on nutrient retention, bone traits and intestinal morphology in broiler chickens. Journal of Animal Physiology and Animal Nutrition 104: 909-917. https://doi.org/10.1111/jpn.13332 